\title{
Legal Ethics and the Destruction of Evidence
}

What if Richard Nixon had burned the tapes? ${ }^{1}$ During the period before the recordings were subpoenaed ${ }^{2}$ when the President could have destroyed the tapes without direct legal consequences, ${ }^{3}$ it is not clear what ethical considerations would have guided presidential counsel in suggesting such action. ${ }^{4}$ The legal or practical consequences of presubpoena destruction often may be insignificant, as illustrated by the recent case of Berkey Photo, Inc. v. Eastman Kodak Co.5 In that case, Kodak lawyers initally claimed that certain documents had been destroyed before trial. ${ }^{6}$ The statement produced little reaction from opposing lawyers or the court. ${ }^{7}$ Only when it later appeared that the documents had not been destroyed and that a Kodak lawyer had lied under oath did the attorneys' conduct draw public criticism. ${ }^{8}$

These two examples illustrate the dilemma facing an attorney whose client may be aided by destroying potentially damaging or embarrass-

1. The existence of a secret system to record conversations and phone calls in Nixon's White House and Executive Office Building offices was revealed July 16, 1973. 1 Conc. Q., Watergate: Chronology of a Crisis 192 (1973).

2. The Senate Select Committee on Presidential Campaign Activities subpoenaed the tapes on July 23, 1973. Id. at 210. The President's legal obligation to surrender 64 tapes subpoenaed on April 18, 1974 by the special prosecutor was upheld in United States v. Nixon, 418 U.S. 683 (1974).

3. The legality of destroying the types would have depended on the factors discussed at pp. 1670-71 infra. If there was a period when destruction was legal, it was probably prior to March 26,1973, the date when the grand jury that indicted the original seven Watergate defendants reconvened to consider new charges. CoNG. Q., supra note 1, at 54. But see R. Ben-Veniste, Stonewall 112 (1977) (special prosecutor's staff believed subpoena-not just existence of grand jury-necessary to prevent destruction of tapes). Legality of the destruction might also have depended on whether the tapes were public or private property. See Ford \& Pollitt, Who Owns the Tapes? 6 N.C. CENT. L.J. 197 (1975).

4. Some attorneys have suggested that they would have had no ethical compunctions about advising destruction of the tapes. E.g., Auletta, Don't Mess With Roy Cohn, Esquire, Dec. 5, 1978, at 59 (attorney says he would have defended Nixon by burning tapes); New Haven Register, Nov. 3, 1978, at 1, col. 3 (former attorney general Richard Kleindienst says Nixon was "stupid" not to burn tapes). When produced, several of the tapes did contain intentional erasures. 2 Conc. Q., supra note 1, at 201.

5. Berkey Photo, Inc. v. Eastman Kodak Co., 457 F. Supp. 404 (S.D.N.Y. 1978), rev'd in part and remanded in part, 48 U.S.L.W. 2001 (July 3, 1979).

6. Berkey Photo, Inc. v. Eastman Kodak Co., 74 F.R.D. 613, 614 n.4 (S.D.N.Y. 1977).

7. The only reference in the record to the destruction was plaintiffs' argument that it provided an additional reason for upholding their subpoena of notebooks prepared by Kodak attorneys and examined by the expert witness. The district court held that the notebooks were attorney work-products and therefore denied the motion. Id.

8. E.g., Kiechel, The Strange Case of Kodak's Lawyers, Fortune, May 8, 1978, at 188 (reporting Kodak's dismissal of the law firm from rest of case); Judge's Letter Spurs Probe by Prosecutor of Kodak's Lawyer, Wall St. J., April 11, 1978, at 1, col. 4 (negative reaction to disclosure that records had not been destroyed). 
ing documents. A lawyer's duty to aid his client may conflict with his duty not to undermine the work of the court. Yet the Code of Professional Responsibility ${ }^{9}$-the primary professional source of ethical guidance for a lawyer-fails to resolve the problems that arise when it appears that a client's position can be improved by destroying evidence. ${ }^{10}$ This Note argues that the Code should confront this situation, and suggests an amendment to the Code to cover such cases.

\section{Current Constraints on the Destruction of Evidence}

The Code of Professional Responsibility does not directly preclude an attorney from advising his client to destroy possible evidence; provisions of the Code refer only to situations in which destruction of evidence is illegal. It is therefore essential to examine relevant state and federal statutes. Because these laws do not cover every situation in which the possibility of destroying evidence arises, the attorney's role may not be governed by current ethical standards. Thus the lawyer is free to base his advice on competing practical considerations.

\section{A. Current Ethical Duties}

The Code of Professional Responsibility addresses the ethical questions raised by the destruction of evidence most directly in the provision that a lawyer should not "[c]onceal or knowingly fail to disclose that which he is required by law to reveal." 11 This provision is simply a specific instance of the general rule that an attorney should not counsel or assist his client in conduct the lawyer knows to be illegal.12

Other provisions of the Code might appear to prohibit a lawyer from advising his client to destroy possible evidence before its production is required by law. These provisions have not been so interpreted, however. For example, although an attorney should not assist his client in

9. ABA Code of Professional Responsibility (1969) (replacing Ganons of Professional. ETHICs (1908)). The Code has been adopted or followed in every state. Rubin, $A$ Causerie on Lawyers' Ethics in Negotiation, 35 LA. L. REv. 577, 579 (1975).

10. See, e.g., Carr v. St. Paul Fire \& Marine Ins. Co., 384 F. Supp. 821, 831 (W.D. Ark. 1974) (destruction of emergency room test results in hospital malpractice suit); Cecil Corley Motor Co., Inc. v. General Motors Corp., 380 F. Supp. 819, 859 (M.D. Tenn. 1974) (destruction of business records in private antitrust suit).

11. ABA Code of Professional Responsibility, Disciplinary Rule 7-102(A) (3) [Disciplinary Rules hereinafter cited as DR without cross-reference]; accord, id., ETHICAL Consideration 7-27 (lawyer should not suppress evidence that he or his client has legal obligation to reveal or produce) [Ethical Considerations hereinafter cited as EC without cross-reference].

12. DR 7-102(A)(7). 
conduct the attorney knows to be fraudulent, ${ }^{13}$ "fraud" almost always means acts of affirmative misrepresentation rather than failure to disclose material facts. ${ }^{14}$ Moreover, the rule that a lawyer should report attempts by his client to perpetrate a fraud ${ }^{15}$ has been weakened considerably by American Bar Association opinions on ethical issues. ${ }^{16}$ In requiring certain kinds of disclosure, some courts have emphasized the lawyer's duty of candor as an "officer of the court,"17 but the required disclosures primarily concern such matters as fraudulent conveyances of clients' assets, ${ }^{18}$ legal proceedings elsewhere, ${ }^{19}$ and special fee arrange-

13. Id. (lawyer shall not counsel or assist client in conduct lawyer knows to be fraudulent); see Gould v. State, 99 Fla. 662, 668, 127 So. 309, 311 (1930) (courts should purge themselves by rezoving any lawyer whose conduct impedes, obstructs, or prevents administration of justice).

14. E.g., Rubin, supra note 9, at $\mathbf{5 8 2}$ (lawyers have no ethical duty to reveal, and indeed may be required to conceal, evidence damaging to client's cause); See ABA CoMM'N on Professional Ethics, Opinions, No. 314 (1965) (attorney in practice before IRS is under no duty to disclose weaknesses of client's case); id., No. 287 (1953) (attorney has no duty to disclose client's admission of perjury in divorce proceeding); $i d$., No. 268 (1945) (attorney need not disclose that client does not meet residence requirements for pending divorce). The lack of a duty to disclose adverse facts contrasts sharply with the attorney's affirmative duty to inform the court of legal authority adverse to the position of his client and not disclosed by opposing counsel. DR 7-106(B)(1); see In re Greenberg, 15 N.J. 132, 104 A.2d 46 (1954) (attorney has duty to inform court of adverse case authority not indicated by opponent).

15. DR 7-102(B)(1).

16. A 1974 amendment to the Code provides that an attorney's duty to report frauds committed by a client against a third party does not apply where it would require violating the rule of confidentiality expressed in ABA CODE of ProfEssional Responsibility CANON 4 (lawyers should preserve secrets and confidences of clients). Since the rule of confidentiality prohibits disclosing anything embarrassing to the client, the amendment "eviscerated the duty to report fraud." G. HAZARD, Ethics in THE Practice of Law 27 (1978); accord, Wolfram, Client Perjury, 50 S. CaL. L. Rev. 809, 836-37 (1977). See also ABA Comm. on Professional Ethics, Opinions, No. 341 (1975) (1974 amendment should be extended to protect secrets and confidences of client from disclosure without regard to whether they would be protected under attorney-client privilege); id., No. 268 (1945) (attorney's duty to disclose fraud upon court does not transcend duty to preserve client's confidences).

17. E.g., State ex rel. Neb. Bar Ass'n v. Niklaus, 149 Neb. 859, 860, 33 N.W.2d 145, 146 (1948) (attorney owes first duty to court); In re O'Brien, 95 Vt. 167, 174, 113 A. 527, 530 (1921) (malpractice for attorney to pollute administration of justice through act or omission).

18. E.g., Florida Bar v. Beaver, 248 So. 2d 477 (Fla. 1971) (attorney suspended for suggesting that client conceal assets during divorce proceeding); In re Shon, 262 A.D. 225, 28 N.Y.S.2d 872 (1941), appeal denied, 287 N.Y. 855 (1942) (attorney disbarred for offenses including advising client to execute chattel mortgage to his mother after commencement of tort action, and causing second client to sign bankruptcy petition that omitted certain liabilities).

19. E.g., Harkin v. Brundage, 13 F.2d 617, 620 (7th Cir. 1926), rev'd on other grounds, 276 U.S. 36 (1928) (ex parte application to obtain "friendly receivership" without informing court of proceedings in second jurisdiction may lead to disbarment); In re Goodrich, III Vt. 156, 11 A.2d 325 (1940) (attorney suspended for not telling court that client in divorce case had been convicted of adultery). 
ments. ${ }^{20}$ The principle of requiring disclosure has been applied to cases in which an attorney tampered with evidence ${ }^{21}$ or witnesses, ${ }^{22}$ but only in the most egregious circumstances.

Prosecutors have a special duty not to destroy evidence that may be helpful to the defense in a criminal action. ${ }^{23}$ Recently, courts also have announced that a defense attorney has a duty to reveal to the prosecution any incriminating evidence received from a client. ${ }^{24}$ This rule rests on a balancing between the attorney-client privilege and the societal interest in controlling crime ${ }^{25}$ and thus does not apply in civil actions. Even in the criminal context, the rule has been severely criticized. ${ }^{26}$

20. E.g., Sullins v. State Bar, 15 Cal. 3d 609, 542 P.2d 631, 125 Cal. Rptr. 471 (1975), cert. denied, 425 U.S. 937 (1976) (suspension for petitioning court to increase contingency fee for representing executor of estate without disclosing beneficiary had withdrawn four years earlier); In re Dangler, 192 A.D. 237, 182 N.Y.S. 471 (1920) (attorney did not disclose fee arrangement to take half of client's alimony in divorce case).

21. E.g., State ex rel. Neb. Bar Ass'n v. Fisher, 170 Neb. 483, 103 N.W.2d 325 (1960) (oneyear suspension for attorney in murder trial who twisted dowel through bullet hole in belt to enlarge size of hole); Cincinnati Bar Ass'n v. Leggett, 176 Ohio St. 281, 199 N.E.2d 590 (1964) (attorney suspended after advising client to burn records illegally because relevant to inquiry of pending federal grand jury).

22. E.g., Louisana State Bar Ass'n v. Sackett, 234 La. 762, 101 So. 2d 661, cert. denied, 358 U.S. 822 (1958) (suspension for offering prosecution witness money to leave jurisdiction of pending trial); In re Hartridge, 162 A.D. 877, 146 N.Y.S. 421 (1914) (attorney disbarred for paying prostitutes not to testify at murder trial).

23. See Brady v. Maryland, 373 U.S. 83, 87 (1963) (suppression by prosecution of evidence favorable to accused violates due process irrespective of prosecution's good faith); Comment, Judicial Response to Governmental Loss or Destruction of Evidence, 39 U. CHI. L. Rev. 542, 565 (1972) (protections offered defendant at trial of little benefit if he has no remedy for loss or destruction of evidence material to defense). The Jencks Act, 18 U.S.C. $\$ 3500$ (1976), entitles defendants to inspect all statements of government witnesses insofar as they relate to the witness's testimony.

24. E.g., In re January 1976 Grand Jury, 534 F.2d 719 (7th Cir. 1976) (affirming contempt citation of attorney for refusing to produce subpoenaed fee received from clients); In re Ryder, 263 F. Supp. 360 (E.D. Va.), aff'd, 381 F.2d 713 (4th Cir. 1967) (18-month suspension of defense attorney who took possession of stolen money and shotgun used by client in bank robbery without informing court).

25. E.g., State ex rel. Sowers v. Olwell, 64 Wash. 2d 828, 832, 394 P.2d 681, 684 (1964) (attorney should reveal client's evidence to prosecution because of public interest in efficient criminal investigations); Note, The Right of a Criminal Defense Attorney to Withhold Physical Evidence Received from His Client, 38 U. CHI. L. REv. 211, 213 (1970) (defendant's interest must be balanced with society's interest in protecting citizens against crime).

26. E.g., Comment, An Attorney in Possession of Evidence Incriminating His Client, 25 WASH. \& LEE L. REv. 133, 136, 140-41 (1968) (inconsistent to require attorney in criminal case to present evidence of client's guilt while asserting his innocence; rule raises more questions than it answers); Comment, Fruits of the Attorney-Client Privilege: Incriminating Evidence and Conflicting Duties, 3 DuQ. U.L. REv. 239, 247 (1965) (court opinions provide little insight into problem of client with incriminating evidence, and lack ethical or legal authority). In particular, commentators have argued that these cases will lead to increased destruction of evidence. E.g., id. at 249-50 (attorney has ethical duty to advise client of adverse consequences from possession of incriminating evidence although that 


\section{Destruction of Evidence}

Thus, while attorneys have both ethical and legal duties not to tolerate perjury ${ }^{27}$ or fabricate evidence, ${ }^{28}$ in most cases they have no duty to volunteer material facts. ${ }^{20}$ The Code of Professional Responsibility's provision on the retention of evidence depends entirely upon the legal duty to preserve it, suggesting that it is not unethical for an attorney to recommend destroying documents or other evidence when it is not illegal for the client to do so. ${ }^{30} \mathrm{It}$ is therefore necessary to examine the laws which establish the illegality of destruction before turning to the problems created by this ethical rule.

\section{B. Statutory Provisions}

There is no federal statute that explicitly makes destruction of evidence a crime. Nevertheless, once documents or other evidence have been subpoenaed, intentional destruction is clearly criminal con-

may be equivalent to advising its concealment or destruction); Note, Professional $R e$ sponsibility and In re Ryder: Can An Attorney Serve Two Masters? 54 VA. L. REv. 145, 164 (1968) (distinct possibility client would have wanted to destroy stolen money, since attorney, in performance of ethical duty, informed client of implications of possession).

27. DR 7-102(A) (4) (lawyer shall not knowingly use perjured testimony or false cvidence); DR 7-102(A)(5) (lawyer shall not knowingly make false statement of law or fact). Some courts have imposed disciplinary measures against attorneys who stood by while their clients committed perjury. E.g., Committee on Professional Ethics v. Crary, 245 N.W.2d 298 (Iowa 1976). But see In re Malloy, 248 N.W.2d 43, 45 (N.D. 1976) (attorney should urge client to disclose perjury and withdraw if client refuses, but need not disclose fraud to court). The duty to disclose perjury does not apply to a lawyer whose client gives false testimony in a criminal case. ABA Project on Standards for Criminal Justice, Standards Rerating to the Prosecution function and the Defense Function, Defense Function $\$ 7.7$, Commentary at 274-77 (Approved Draft 1971); see Lowery v. Cardwell, 575 F.2d 727, 731 (9th Cir. 1978) (violation of due process and right to fair trial for defense counsel to seek leave to withdraw from criminal case because he believes client is lying on stand).

The appropriate response for a lawyer when a client commits perjury has long been a troublesome ethical issue for the legal profession. Consider the debates touched off by Curtis, The Ethics of Advocacy, 4 Sran. L. REv. 3, 9, 11 (1951) (lawyer may sometimes have to lic for client) and Freedman, Professional Responsibility of the Criminal Defense Lawyer: The Three Hardest Questions, 64 Mich. L. REv. 1469, 1469, 1482 (1966) (adversary system requires putting defendant on stand even when lawyer knows he will commit perjury). See generally Wolfram, supra note 16.

28. DR 7-102(A)(6) (lawyer should not participate in creation of false evidence). An attorncy may never advise the falsification of a client's papers or records in anticipation of a subpoena. Submission of falsified documents is a violation of 18 U.S.C. $\$ 1503$ (1976), see, e.g., Bosselman v. United States, 239 F. 82, 85 (2d Cir. 1917) (alteration of sales list and shipping book), or 18 U.S.C. $\$ 1505$ (1976), see, e.g., United States v. Vixic, 532 F.2d 1277 (9th Cir. 1976) (submission of falsified documents to IRS); United States v. Fruchtman, 421 F.2d 1019 (6th Cir.), cert. denied, 400 U.S. 849 (1970) (submission of false invoices to FTC). Once a subpoena is served, a party that has previously falsified documents can neither produce nor destroy them without violating the obstruction-of-justice statutes. See note 32 infra.

29. See note 14 supra.

30. See note 87 infra. 
tempt ${ }^{31}$ or obstruction of justice ${ }^{32}$ under federal law. Even before the issuance of a subpoena, the destruction of documents has been held to be a criminal offense ${ }^{33}$ provided two conditions are met. First, the documents must be relevant ${ }^{34}$ to a pending ${ }^{35}$ grand jury or criminal investigation, ${ }^{36}$ and second, the intent of the actor must be "cor-

31. Disobedience or resistance to lawful process or a lawful order of a court is punishable as a criminal contempt under 18 U.S.C. $\$ 401(3)$ (1976) and FED. R. Crim. P. 17(g). See, e.g., United States v. Boudreaux, 328 F. Supp. 154, 155 (E.D. La. 1971) (contcmpt for violating court order to preserve all materials pending further adjudication); In re D.I. Opcrating Co., 240 F. Supp. 672 (D. Nev. 1965) (contempt for reckless disregard of duty to preserve materials summoned by IRS). The contempt citation has a limited applicability, however, because it covers only violation of court orders or misbehavior in the vicinity of the court that disrupts its quiet, order or business. Nye v. United States, 313 U.S. 33, 52 (1941); see Millinocket Theatre, Inc. v. Kurson, 39 F. Supp. 979, 980 (D. Me. 1941) (court lacks authority to punish defendant for criminal contempt when he destroyed records material to pending suit before issuance of subpoena). Defiance of a subpoena in order to suppress evidence does not necessarily lead to a contempt citation because enforcement can be awkward and expensive. International Union (UAW) v. NLRB, 459 F.2d 1329, 1338-39 (D.C. Cir. 1972).

32. 18 U.S.C. $\$ 1503$ (1976) concludes with a general prohibition of conduct that "corruptly .. influences, obstructs, or impedes, or endeavors to influence, obstruct, or impede, the due administration of justice ...." The section applies to trials, grand juries, and conduct aimed at court officials and jurors. $I d$. 18 U.S.C. $\$ 1505$ (1976), using similar language, applies to administrative agencies and congressional committees.

The statutes have been held to proscribe the destruction of subpoenaed documents. See, e.g., United States v. Walasek, 527 F.2d 676, 679 (3rd Cir. 1975) (adjudicating 18 U.S.C. $\S 1503$ ); United States v. Presser, 187 F. Supp. 64, 66 (N.D. Ohio), aff'd, 292 F.2d 171 (6th Cir. 1971), aff'd by an equally divided court, 371 U.S. 71 (1962) (adjudicating 18 U.S.C. $\$ 1505)$.

33. See, e.g., United States v. Fineman, 434 F. Supp. 197, 202 (E.D. Pa. 1977), aff'd mem., 571 F.2d 572 (3rd Cir.), cert. denied, 436 U.S. 945 (1978) (obstruction statute applies to person who knows grand jury is investigating possible violations, has reason to believe document will be wanted, and destroys document to prevent its production); United States v. Solow, 138 F. Supp. 812, 815 (S.D.N.Y. 1956) (upholding indictment against defendant who agreed to produce letters for grand jury without formal process, then destroyed them).

34. The mere fact documents have been subpoenaed does not establish their relevance. See United States v. Ryan, 455 F.2d 728, 734 (9th Cir. 1972) (reversing conviction under 18 U.S.C. $\$ 1503$ for destruction of subpoenaed corporate records; destroyed documents must bear reasonable relationship to subject matter of grand jury inquiry); United States v. Siegel, 152 F. Supp. 370, 374 (S.D.N.Y. 1957), aff'd, 263 F.2d 530 (2d Cir.), cert. denied, 359 U.S. 1012 (1959) (dictum) (destruction of papers, like any act alleged to obstruct grand jury investigation, must bear reasonable relationship to subject matter of inquiry to constitute obstruction of justice).

35. A grand jury may become "pending" even before it hears testimony or decides to issue a subpoena, thus bringing subpoenas issued by a prosecutor on its behalf under the aegis of 18 U.S.C. $\$ 1503$. United States v. Walasek, 527 F.2d 676, 678 (3d Cir. 1975).

36. Concerned about the refusal of some courts to apply 18 U.S.C. $\$ 1503$ to cases involving the intimidation of prospective witnesses, see note 38 infra, Congress enacted 18 U.S.C. $\$ 1510$ (1976) "to 'plug a loophole' . . . by applying criminal sanctions to interference with the criminal investigative process." United States v. Mitchell, 372 F. Supp. 1239, 1250-51 (S.D.N.Y.), app. dismissed, 485 F.2d 1290 (2d Cir. 1973). While the statute was intended primarily to protect potential witnesses, it may also apply to document destruction intended to impede a criminal investigation. United States v. Fineman, 434 F. Supp. 197, 202 (E.D. Pa. 1977), aff'd mem., 571 F.2d 572 (3d Cir.), cert. denied, 436 U.S. 945 (1978) (dictum). 
rupt." ${ }^{37}$ To justify these holdings, however, judges have had to struggle to show that the proscribed conduct fell within the narrow wording of the federal obstruction-of-justice statutes. ${ }^{38}$ Under federal law it is not illegal to destroy a document, no matter how relevant to future litigation, provided no subpoena has been issued and no grand jury or criminal investigation has yet begun. ${ }^{39}$

Roughly half the states have enacted statutes proscribing the destruction of evidence that have a broader scope than current federal law. These state provisions, which generally are similar to the relevant provision of the Model Penal Code, ${ }^{40}$ prohibit destroying documents

37. The word "corrupt" in the obstruction-of-justice statutes, 18 U.S.C. $\$ \$ 1503,1505$ (1976), has been defined to mean "an evil or wicked purpose." United States v. Ryan, 455 F.2d 728, 734 (9th Cir. 1972). Thus, specific intent is an essential element of the offense. Id. The test is subjective, requiring actual knowledge or belief that the acts done will obstruct justice. United States v. Solow, 138 F. Supp. 812, 816 n.14 (S.D.N.Y. 1956); see Odom v. United States, 116 F.2d 996, 999 (5th Cir.), rev'd per curiam, 313 U.S. 544 (1941) (error to charge jury that it is sufficient for conviction to find that defendant had reasonable grounds to believe victim of beating was witness in another suit).

When the requisite intent is not present, it is not a crime to destroy documents. In United States v. Ryan, 455 F.2d 728 (9th Cir. 1972), the evidence was held insufficient to establish such an intent when the subpoenas were issued to Ryan after the government learned that he had begun to destroy his records. $I d$. at 734 .

38. The omnibus clause in the obstruction-of-justice statutes has come under attack as unconstitutionally vague and lacking in fair notice of the prohibited conduct, in particular because the specific portions of 18 U.S.C. $\$ 1503$ apply only to influencing or intimidating witnesses, jurors or court officials. E.g., United States v. Howard, 569 F.2d 1331, 1336.37 (5th Cir. 1978); Anderson v. United States, 215 F.2d 84 (6th Cir.), cert. denied, 348 U.S. 888 (1954) (upholding statute against challenge for vagueness). The circuit courts have split on how broadly to interpret the omnibus clause. Some courts have applied the ejusdem generis rule, under which the specific language of a statute modifies the general language, and have held that the statute proscribes only acts similar in manner to those proscribed by the specific language. E.g., United States v. Metcalf, 435 F.2d 754 (9th Cir. 1970); United States v. Essex, 407 F.2d 214 (6th Cir. 1969). Other courts have adopted the broad rule that the statute proscribes all acts similar in result to those specified. E.g., United States v. Howard, 569 F.2d 1331 (5th Cir. 1978); United States v. Walasek, 527 F.2d 676, 681 (3rd Cir. 1975) (ejusdem generis rule does not preclude conviction for destroying subpoenaed documents).

The application of the obstruction statutes is even less clear in the case of destruction before documents have been subpoenaed. United States v. Solow, 138 F. Supp. 812 (S.D.N.Y. 1956) (upholding indictment for destruction of letters before subpoena but after defendant had agreed to submit them to grand jury) was criticized as a decision "to expand the scope of the law unduly" to accommodate a new situation. Comment, 31 ST. JoHN's L. Rev. 129, 132 (1956); see Working Papers of the National Commission on Reform of Federal Criminal Laws 568 (1970) [hereinafter cited as Working Papers] (current obstruction statutes provide "neither standards sufficient to predict whether particular conduct is condemned nor adequate guidance to make important policy distinctions between related kinds of conduct").

39. This is not true, of course, of records required to be kept by other state or federal laws. See Shapiro v. United States, 335 U.S. 1 (1948).

40. Model Penal Code $\$ 241.7$ (Proposed Official Draft 1962) (misdemeanor to destroy document or other real evidence if, "believing that an official proceeding or investigation is pending or about to be instituted," person acts "with purpose to impair its verity or availability in such proceeding or investigation"). 
or other real evidence with intent to impair their availability in a prospective proceeding when the evidence is "about to be produced." 41 In other states, however, statutes apply only to the destruction of evidence that may be pertinent to criminal proceedings, ${ }^{42}$ or parallel the federal obstruction-of-justice statutes ${ }^{43}$ and apply only to pending proceedings. In some states, destruction of evidence while a grand jury or criminal investigation is pending is a common-law offense..$^{44}$

A final category of statutes, currently adopted by six states, ${ }^{45}$ extends the prohibition against destroying evidence even further than the Model Penal Code provision by making destruction of real evidence a criminal offense if done with intent to prevent its production in a trial or other legal proceeding regardless of the time of the act. ${ }^{46}$ Similarly, the proposed Criminal Justice Improvement Act of $1978^{47}$ included a section that proscribed destruction of documents or other real evidence at any time if the actor intended to prevent their availability in any future civil or criminal proceeding. ${ }^{48}$

\footnotetext{
41. E.g., Cal. Penal Code $§ 135$ (West 1970); N.Y. Penal Law $\S 215.40(2)$ (McKinney 1975).

42. E.g., Fla. Stat. \$ 918.13(1)(a) (1975); Iowa Code ANN. \$ 719.3(1) (West Supp. 1978).

43. E.g., MD. CRIM. Code ANN. § 27 (1976); R.I. GeN. LAws § 11-32-3 (Supp. 1977). Other states have obstruction-of-justice statutes explicitly limited to the use of force or threats. E.g., Kan. STAT. ANN. § $21-3816$ (1974); Mass. Ann. Laws ch. 268, § 13B (Michic/ Law. Co-op Supp. 1978).
}

44. See, e.g., Agnew v. Parks, 172 Cal. App. 2d 756, 766, 343 P.2d 118, 124 (1959) (concealing or withholding documentary evidence was common-law crime of obstruction of justice); State v. Cassatly, 93 N.J. Super. 111, 119, 225 A.2d 141, 144-45 (App. Div. 1966), app. denied, 48 N.J. 448, 226 A.2d 435 (1967) (refusal to produce tape recordings constituted obstruction even before formal proceedings because defendant knew police wanted evidence). But see State v. Stapleton, 539 S.W.2d 655, 658 n.l (Mo. Ct. App. 1976) (restraints on lawyer only ethical when state has no law on issue).

45. Alaska Stat. $\$ 11.56 .610($ a)(1) (Supp. 1978) (effective 1980); 1975 Ark. Acts 659 (to be codified at ARk. STAT. $\$ 41-2611$ ); IND. Code ANN. \$ 35-44-3-4(b)(1) (Burns 1979); MINN. Stat. ANN. \$ 609.63(1)(7) (West 1964); Mo. ANN. Stat. \$ 575.100(1)(1) (Vernon Supp. 1978); Nev. Rev. STAT. \$ 199.220 (1973).

46. See, e.g., In re Williams, 221 Minn. 554, 563, 23 N.W.2d 4, 9 (1946) (citing predecessor to MINN. STAT. ANN. $\$ 609.63(1)(7)$ (West 1964) to affirm disbarment of attorney for advising co-conspirator to destroy decedent's instructions for distribution of property, prior to the commencement of any legal proceedings, in attempt to convert estate).

47. S. 1437, 95th Cong., 2d Sess. (1978), reprinted in XIII Reform of the Federal Criminal Laws: Hearings on S. 1437 Before the Subcomm. on Criminal Laws and Procedures of the Sen. Comm. on the Judiciary, 95th Cong., Ist Sess. 9485-9792 (1977).

48. Id. $\$ 1325$ (a) at $9551-52$. The section also precluded the defense that the documents would have been legally privileged or inadmissible in evidence, a provision intended to overrule Neal v. United States, 102 F.2d 643 (8th Cir. 1939), cert. denied, 312 U.S. 679 (1941) (not misprision under 18 U.S.C. $\$ 4$ (1976) to conceal relevant items whose evidentiary nature was not established). S. REP. No. 95-605, 95th Cong., Ist Sess. 293 n.24 (1977). The House version of the act, H.R. 13,959, 95th Cong., 2d Sess. $\$ \$ 6903,6905$ (1978) would have left the current obstruction-of-justice statutes unchanged. Consideration of the Act was indefinitely postponed when Congress was unable to reach agreement in 1978. 36 CONG. Q. WEEKLY REP. 3353 (1978). 
Statutes concerning the retention of evidence are thus of two kinds: those that focus both on the time of the destruction and the intent of the actor, and those that simply focus on the intent to suppress evidence. The latter seem preferable, since the legality of an act that is intended to obstruct justice should not depend on such fortuities as whether a subpoena has been served or whether a judicial proceeding has begun. ${ }^{40}$ The great majority of jurisdictions, however, rely on the first kind of statute.

\section{Statutory Shortcomings and Practical Considerations}

Since statutory law does not prohibit the destruction of possibly relevant evidence in all situations, current ethical standards do not always prevent an attorney from advising such destruction. Thus the attorney must base his advice on competing practical considerations rather than on legal or ethical standards.

Because some statutes proscribe the destruction of evidence only when legal proceedings are possible, individuals often can dispose of relevant documents without criminal liability. Liability is founded on subjective standards concerning the actor's belief or knowledge about the possibility of legal action. ${ }^{50}$ These standards, as a result of inherent vagueness, permit the legal destruction of relevant evidence in many situations..$^{51}$ Since an attorney's advice about destruction is not unethical so long as the client's act is legal,,$^{52}$ it appears to be ethical for a

49. See Comment, supra note 38 , at $132-33$ (proposing change in federal obstructionof-justice statutes to prohibit destruction of documents with intent to make them unavailable for trial regardless of immediacy of legal proceedings).

50. Some state statutes prohibit destruction of evidence when the actor "believes" that a proceeding is about to be instituted. E.g., DeL. CoDE ANN. tit. 11, § 1269(2) (1974); 18 Pa. Cons. Stat. ANN. $\$ 4910$ (1) (Purdon 1973). Other states limit this prohibition to situations where the actor "knows" such a proceeding is about to take place, e.g., OHIo Rev. Code Ann. § 2921.12(A)(I) (Page 1975); Tex. Penal Code Ann. tit. 8, \$ 37.09(A)(1) (1974), and still others limit the former construction with the phrase "and [is] acting without legal right or authority." E.g., ALA. CoDE $\S 13 A-10-129$ (a)(I) (Supp. 1978); WASH. REv. CodE ANN. \$ 9A.72.150(1)(a) (1977). Similar wording was proposed for Mich. Rev. Crim. Code $\$ 5045$ (1967) (not enacted) because "there may be some dispute as to whether a person does not have a lawful right to destroy evidence before it has been seized or subpoenaed." Special Committee for the Revision of the Criminal Code, State Bar of Michigan, Mich. Rev. Crim. Code 418 (Final Draft 1967).

51. For example, it is not clear what degree of certainty is required to "know" or "believe" that cvidence will be relevant or required in a later proceeding. See, e.g., People v. Nicholas, 93 Misc. 2d 1037, 1039, 403 N.Y.S.2d 683, 684-85 (Sup. Ct. 1978) (no indictment for tampering with evidence where defendant helped dispose of murder victim's body, since disposal occurred before criminal proceedings instituted). Moreover, a client who blindly follows his attorney's advice to destroy documents cannot by definition have the corrupt motive required by these criminal statutes.

52. See p. 1666 \& note 11 supra. 
lawyer in these situations to advise destroying documents that may be relevant to a future legal proceeding.

Even the category of statutes that focuses entirely on the intent to suppress evidence rather than on the timing of the destruction cannot completely eliminate the influence of the pendency of legal proceedings on the lawyer's advice. When the act of seeking a lawyer's advice about destruction indicates a corrupt motive on the part of the client, ${ }^{53}$ the lawyer's duty is clear: he can not help or participate in the illegal action. More often, however, the client's motives are unclear. In these situations, an attorney must wrestle with the troublesome problem of assessing his client's motives. ${ }^{54}$ The Code of Professional Responsibility suggests that an attorney who is forced to guess at his client's motives should resolve reasonable doubts in favor of the client. ${ }^{55}$ It is at this stage that the pendency of a formal proceeding will continue to be significant: if no legal action is pending, a client's motives appear less corrupt and destruction more legal.56 Thus, even statutes that simply focus on the intent to keep evidence from use in a legal action will not eliminate the attorney's role in the destruction of potentially relevant evidence. ${ }^{57}$

In situations in which destruction is not clearly illegal and thus not unethical, an attorney is likely to base his advice on practical considera-

53. It is arguable that whenever an attorney participates in the destruction of documents, he necessarily does so with future litigation in mind. Thus, in the few jurisdictions where it is criminal to destroy evidence with intent to prevent its use at trial regardless of the time of the destruction, see note 45 supra, an active role by the attorney might be sufficient to establish the proscribed intent. This will not always be true, however, when it is the client who approaches the attorney. See notes 54-56 infra.

54. See Working Papers, supra note 38, at 575 ("[T]ampering with physical evidence often can involve ambiguous acts which may or may not be unlawful without the requisite purpose. The purpose in destroying a record, for example, may be wholly unexpressed except by the ambiguous and often private conduct of destruction.") Moreover, the law is not clear whether culpability exists when the actor's motives are mixed. In United States v. Fayer, 523 F.2d 661 (2d Cir. 1975), the government appealed an acquittal because "the trial judge misconstrued the statute to require that the corrupt motive of a defendant be predominant or exclusive ...."Id. at 662. The appellate court affirmed, though it noted that the trial judge had "very probably misconstrued the statute." Id.; see Working Papers, supra note 38 , at 569, 579 (term "corruptly" has no generally accepted meaning; culpability requirement imposed by courts is unclear and sometimes contradictory).

55. EC 7-6 (where client's intent, motives or desires determine whether a course of conduct is legal and lawyer is not certain about client's state of mind, he should resolve reasonable doubts in favor of client); see EC 7-3 (as advocate, lawyer should resolve doubts as to bounds of the law in favor of his client).

56. See ALA. CODE $\$ 134-10-129$ note, at 253 (Supp. 1978) (likelihood or remoteness of proceeding will have substantial bearing on prosecutor's ability to meet burden of proof); Working PaPers, supra note 38, at 575 (proof of culpability will usually be by proof of pendency or notice of actual or prospective proceedings).

57. A statute could conceivably prohibit the destruction of personal property cven by its owners, or require that all documents and papers be saved, but such a statute is clearly not practical or enforceable. 
tions. Certain considerations mitigate against advising destruction. The destruction of a document to prevent its use at trial precludes that party from later introducing secondary evidence to prove the document's contents, ${ }^{58}$ but does not bar the opposing party from doing so. ${ }^{59}$ Moreover, the intentional destruction of a document to prevent its use at trial, even when not illegal, creates an adverse inference that a party's whole case is weak. ${ }^{60}$ Finally, any questions asked of a client under oath concerning the destruction must be answered honestly to avoid outright perjury. ${ }^{61} \mathrm{It}$ is possible that the answers will be as damaging as the actual contents of the destroyed documents. ${ }^{62}$

Other practical considerations encourage attorneys to advise destruction of documents before or even after an action has started. If an attorney feels that a document is confusing or misleading, he may not wish to take time to explain it in court. ${ }^{63}$ In addition, recent develop-

58. FED. R. Evm. 1002 (best evidence rule) requires the original writing to prove the contents of the writing. See, e.g., Sylvania Electric Products, Inc. v. Flanagan, 352 F.2d 1005, 1008 (Ist Cir. 1965) (sccondary evidence of work by plaintiff inadmissible without showing why plaintiff had not submitted daily time sheets or why he had destroyed them); Sellmayer Packing Co. v. Commissioner, 146 F.2d 707, 711 (4th Cir. 1944) (secondary evidence inadmissible to prove contents of sales slips and invoices which taxpayer claimed had been accidentally destroyed when "the only logical conclusion was that they had been deliberately destroyed to prevent their production at the hearing").

59. E.g., Womack v. State, 145 Tex. Crim. 551, 170 S.W.2d 478 (1943) (state may prove contents of defendant's letters to prosecutrix, even though prosecutrix destroyed them and did not testify).

60. Courts have instructed juries that they may draw the strongest possible inferences against partics that destroy documents in order to prevent their use during litigation. E.g., Bird Provision Co. v. Owens County Sausage, Inc., 379 F. Supp. 744, 751 (N.D. Tex. 1974), aff'd, 568 F.2d 369 (5th Cir. 1978) (court may draw unfavorable inferences against any party that destroys, alters or fabricates evidence); A.C. Becken Co. v. Gemex Corp., 199 F. Supp. 544, 553 (N.D. Ill. 1961), aff'd, 314 F.2d 839 (7th Cir.), cert. denied, 375 U.S. 816 (1963) (destruction of documents during litigation is admission such evidence would be damaging).

61. See note 27 supra. Similarly, presubpoena destruction of documents encounters the practical objection that a copy of the document may be overlooked and remain in the client's files, where it may turn up in the discovery process. FED. R. CIv. P. 34 provides that parties may demand to inspect and copy documents in the possession, custody or control of another party after the commencement of an action. Any uncertainty as to an cthically appropriate course of action ceases after such a demand is made. See Norman v. Young, 422 F.2d 470, 474 (10th Cir. 1970) (active refusal to comply with document demand, such as destruction or concealment of requested documents, constitutes direct flaunting of court's authority and justifies entry of default judgment).

62. This is not always true, however. Less damage is incurred if the witness's answer is, "On the advice of my attorney, $I$ destroyed the document because it was not material to this case," see note 95 infra, or that the document was destroyed as part of a routine document retention program, see note 74 infra.

63. One example of such a document might be an interim report from an expert witness. An additional problem for Kodak's lawyers in Berkey Photo, Inc. v. Eastman Kodak Co., 457 F. Supp. 404 (S.D.N.Y. 1978), rev'd in part and remanded in part, 48 U.S.L.W. 200I (July 3, 1979), concerned a six-page letter from an expert witness that the law firm did not produce in response to a document demand. Kiechel, supra note 8 , at 190 (interim report was type of document lawyers hope to find during discovery, containing "carly wavering" that can be used to cast doubt about witness's credibility). 
ments in other areas of the law provide reasons for favoring destruction. For example, in announcing the duty of defense counsel to provide the prosecution with incriminating evidence received from the client, courts ignored the obvious incentive created for criminal defendants to destroy such evidence rather than turn it over to their attorneys. ${ }^{64}$ While courts have justified expanded police powers of search and seizure on the grounds that evidence may be destroyed if the authorities have to obtain warrants in all cases, ${ }^{65}$ these expanded powers may encourage even more destruction. The narrowing protections of the Fourth ${ }^{66}$ and Fifth ${ }^{67}$ Amendments may lead an attorney to feel that the only way to keep certain evidence out of court is to destroy it altogether, ${ }^{68}$ or, in the case of documents, to recommend that they never be created. ${ }^{69}$ Even if the fact of destruction is established

64. See note 26 supra.

65. See, e.g., Zurcher v. Stanford Daily, 436 U.S. 547, 561 \& n.8 (1978) (search warrant held valid against college newspaper that had policy of destroying photographs; result partly justified by dangers of destruction and removal caused by delay involved in subpoena duces tecum); Sellmayer Packing Co. v. Commissioner, 146 F.2d 707, 711-12 (4th Cir. 1944) (not unreasonable search and seizure for revenue agents, suspecting records were being altered and destroyed, to remove sample records without taxpayer's knowledge).

66. U.S. Const, amend. IV; see, e.g., United States v. Miller, 425 U.S. 435 (1976) (defendant has no Fourth Amendment interest sufficient to challenge seizure of bank's records under defective subpoena); Warden v. Hayden, 387 U.S. 294, $301-02$ (1967) (search warrants can be used to seize "mere evidence" as well as instrumentalities and fruits of crime).

67. U.S. Const. amend. V; see, e.g., Fisher v. United States, 425 U.S. 391 (1976) (subpoena for accountant's tax memorandum can be enforced against attorney holding it for client, irrespective of any Fifth Amendment privilege in hands of client); Andresen v. Maryland, 427 U.S. 463 (1976) (upholding warrant to search defendant's law office for incriminating financial records). These cases have received substantial criticism. E.g., McKenna, The Constitutional Protection of Private Papers: The Role of a Hierarchical Fourth Amendment, 53 IND. L.J. 55, 67 (1977) (Fisher and Andresen decisions demonstrate Fifth Amendment no longer protects private papers from governmental procurement).

Several commentators have suggested that these decisions will have an effect on the way individuals handle their documents. E.g., Mahon, Privileged Communications and SelfIncrimination, 32 N.Y.U. INST. FED. TAX. 1251, 1265-66 (1974) (after Couch v. United States, 409 U.S. 322 (1973), holding taxpayers have no right to assert Fifth Amendment privilege with respect to records in possession of third party, "accountants should clean out their file rooms by returning to their clients records which have been gathering dust for years"); Comment, A Paper Chase: The Search and Seizure of Personal Business Records, 43 Brooklyn L. Rev. 489, 506 (1976) (Andresen "gives warning that private thoughts may be safer left unwritten, and ... the paper shredder may become as valuable an accoutrement to crime as the bug-detector").

68. See Meltzer, Required Records, the McCarran Act, and the Privilege Against SelfIncrimination, 18 U. CHI. L. Rcv. 687, 701 (1951) ("A party directed to produce an incriminating document would be tempted to destroy, conceal, or withhold it rather than to incriminate himself.")

69. See, e.g., J. Goulden, The Superlawyers 292 (1972) (attorneys give clients "obvious advice" that before client puts something on paper, client should think how it would sound in court); L. NIzER, MY LIFE IN CourT 519 (1963 ed.) (unwise for insurgent director to write hostile letter to corporate president setting forth doubts about tax situation which, in words of president, "might later be distorted by tax authorities"). 
in court, whether to draw an adverse inference is a question for the jury. ${ }^{70}$ This inference can be rebutted in a number of ways. The client may truthfully testify that the document was irrelevant, ${ }^{71}$ was destroyed long before litigation began, ${ }^{72}$ or was destroyed in reliance on the attorney's advice. ${ }^{73}$ Evidence that the destruction was routine, as under a document retention program, ${ }^{74}$ also rebuts any adverse inference. ${ }^{75}$

These competing practical considerations often must determine the advice an attorney gives his client about the destruction of possibly

70. See, e.g., Wong v. Swier, 267 F.2d 749, 759 (9th Cir. 1959) (weight to be given tampering or suppression of evidence is for jury to decide); 21 C. Wright \& K. GrahaM, Federal Practice and Procedure $\$ 5124$ (1977) (destruction of documents gives rise to permissible adverse inference, not mandatory presumption). But see International Union (UAW) v. NLRB, 459 F.2d 1329 (D.C. Cir. 1972) (NLRB's failure to apply adverse inference against company that had refused for seven years to produce requested documents held reversible error).

71. See, e.g., Drosten v. Mueller, 103 Mo. 624, 633-34, 15 S.W. 967, 970 (1891) (reversing application of adverse inference because facts showed destroyed document was irrelevant to plaintiff's casc); cf. Crosby v. Little River Sand \& Gravel Dev., 212 La. 1, 10-11, 31 So. 2d 226, 228 (1947) (destruction of job cards did not raise inference because same information kept clsewhere).

72. See, e.g., Berthold-Jennings Lumber Co. v. St. Louis R.R., 80 F.2d 32 (8th Cir. 1935), cert. denied, 297 U.S. 715 (1936) (intentional destruction of waybills over nine years old not fraudulent); Schrocdl v. McTague, 256 Iowa 772, 129 N.W.2d 19 (1964), aff'd, 259 lowa 627, 145 N.W.2d 48 (1966) (secondary evidence admissible to prove contents of letters allegedly showing indebtedness when plaintiffs destroyed originals, because letters written over 10-year period and plaintiffs did not ordinarily keep old letters). Accidental or negligent destruction also rebuts the inference, because these do not prove a party's awareness of the weakness of his case. E.g., Allen v. Commissioner, 117 F.2d 364, 368 (1st Cir. 1941) (no adverse inference where corporate books and records destroyed by hurricane and flood); Universe Tankships, Inc. v. United States, 388 F. Supp. 276, 286 (E.D. Pa. 1974), aff'd, $528 \mathrm{~F} .2 \mathrm{~d} 73$ (3rd Cir. 1975) (no adverse inference where destruction of evidence showed "mere negligence").

73. See, e.g., In re Eno's Will, 196 A.D. 131, 164, 187 N.Y.S. 756, 780 (1921) (no adverse inference where beneficiary burned decedent's personal letters on advice of attorney; trial evidence concerning attorney's advice and ensuing destruction "was highly prejudicial and permitted the jury to draw unwarranted inferences"); cf. McDonald v. United States, 89 F.2d 128, 137 (8th Cir.), cert. denied, 301 U.S. 697 (1937) (government's case not affected by official who destroyed evidence; odium is personal).

74. See, e.g., Vick v. Texas Employment Comm'n, 514 F.2d 734, 737 (5th Cir. 1975) (no adverse inference because records destroyed under routine office procedures); Millinocket Theatre, Inc. v. Kurson, 39 F. Supp. 979, 980 (D. Me. 1941) (destruction part of regular routinc). But cf. J. Goulden, supra note 69, at 292 (quoting attorney who calls record retention program "basic preventive maintenance"); G. HAZARD, supra note 16, at 85 (c) nic's ideal blend of ethics and opportunism is to say that lawyer may not counsel systematic destruction of records that might be needed under tax or antitrust laws, but lawyer can advise on legal aspects of records retention policy).

75. Courts may indicate disbelief of the proffered explanations for the destruction without nccessarily invoking the adverse inference. See, e.g., United States v. Johnson, 337 F.2d 180, 201-02 (4th Cir. 1964), aff'd on other grounds, 383 U.S. 169 (1966) (unsatisfactory for IFBI to claim notes on conversations with witnesses were destroyed under routine procedures, when same problem arises repeatedly); SEC v. Rega, [1975 Transfer Binder] FED. SEC. LAw REP. (CCH) 9 95,222, at 98,142 n.7 (S.D.N.X. 1975) ("All the old records were ... subscquently destroyed after they were allegedly damaged in a "flood." ") 
relevant evidence. The ethical guidelines of the Code of Professional Responsibility simply do not reach the difficult situations.

\section{Inadequacies of Current Ethical Standards}

Two principal assumptions of the adversary system are violated by permitting attorneys to advise the destruction of possible evidence. First, by permitting exploitation of the lawyer's legal skills on behalf of the client at too great a cost to other parties, current ethical provisions undermine the commitment to putting equal parties in equal positions. Second, by granting the attorney too much unreviewable discretion in deciding whether to advise the destruction of possible evidence, existing ethical standards contravene the doctrine that all actions affecting the outcome of legal disputes should be reviewable.

\section{A. Exploitation of the Lawyer's Legal Skills}

The adversary system assumes equalization between parties to a legal action, ${ }^{76}$ each with maximum access to all relevant information ${ }^{77}$ and a chance to present that information in its best light to a neutral trier of fact and law. ${ }^{8}$ The failure of the Code of Professional Responsibility to prohibit an attorney from advising his client to destroy documents unless the act is illegal undermines this commitment to the equalization of parties. The lack of ethical guidelines, when coupled with the Code's emphasis on undivided, zealous loyalty to the client, ${ }^{79}$ may lead

76. See, e.g., Leff, Law and, 87 YALE L.J. 989, 996 (1978) (trials required to operate under "almost a weird symmetry"; no party has opportunity not shared by the other); cf. Hew v. Aruda, 51 Hawaii 451, 455-56, 462 P.2d 476, 479-80 (1969) (since purpose of dead man's statutes is to equalize parties, hearsay rule should not bar admission of decedent's declarations when law changes to admit surviving party's testimony).

77. See, e.g., Hickman v. Taylor, 329 U.S. 495, 507 (1947) (mutual knowledge of all relevant facts gathered by both parties essential to proper litigation); H. DRINKER, LEGaL ETHICs 76 (1953 ed.) (theory of adversary system is that justice best accomplished by having all facts on each side investigated and presented with maximum vigor by opposing counsel for decision by court and jury).

78. It is argued that this system best leads to the truth. See, e.g., Tehan v. United States ex rel. Shott, 382 U.S. 406, 416 (1966) (basic purpose of trial is determination of truth); In re Selser, I5 N.J. 393, 405, 105 A.2d 395, 401 (1954) (fundamental theory of judicial system is fullest disclosure best leads to truth and justice).

79. ABa Code of Professional Responsibility Canon 7 (lawyer should represent client zealously within the bounds of law). The principle of undivided, zealous loyalty is an old one. It has received extensive criticism, however, e.g., Frankel, The Search for Truth: An Umpireal View, 123 U. PA. L. Rev. 1031, 1038 (1975) (cthical standards that command loyalty and zeal to client but no positive obligation to truth lead counsel to employ tricks and stratagems to distort truth); Rubin, supra note 9, at 585, 587 (making fidclity to client the ultimate loyalty appears to sanction abdication of personal ethical responsibility), as well as considerable support, e.g., Curtis, supra note 27, at 3 (lawyer's first duty is to client); Fried, The Lawyer as Friend: The Moral Foundations of the LawyerClient Relation, 85 YALE L.J. 1060, 1088 (1976) (morally right that lawyers adopt as dominant purpose furthering of client's interests instead of collective good). 
the attorney to suggest destruction whenever it will help his client. Thus, the attorney may recommend destruction even though he knows that it will deprive other parties of their right to discover all evidence necessary to prove their claims. ${ }^{80}$

Potentially valuable evidence is lost to the judicial system whenever anyone destroys property that may be relevant to a later legal action, but the risk of loss is especially great when lawyers participate in the destruction. ${ }^{81}$ Courts have recognized that an enormous change occurs when an attorney becomes a participant in establishing fact situations rather than taking them as he finds them. ${ }^{82}$ Although an attorney has only a minimal obligation to volunteer information damaging to his client, ${ }^{83}$ his motivation to serve his client's interests does not excuse his efforts to suppress facts in order to prevent others from ever discovering them..$^{8 t}$ It is important to distinguish between the attorney's in-

80. Courts have been extremely critical of prosecutors who destroy evidence that might be helpful to the defense. See, e.g., Jackson v. Wainwright, 390 F.2d 288, 295 (5th Cir. 1968) (purpose of duty to preserve evidence is to insure fair trial for accused); People v. Betts, 272 A.D. 737, 74 N.Y.S.2d 791 (1947), aff'd, 297 N.Y. 1000, 80 N.E.2d 456 (1948) (improper for policeman to destroy notes after dictating complaint in order to avoid crossexamination on them). But see Killian v. United States, 368 U.S. 231, 242 (1961) (pretrial destruction of FBI notes on informer's expenses was harmless error); United States v. Sewar, 468 F.2d 236 (9th Cir. 1972), cert. denied, 410 U.S. 916 (1973) (evidence not suppressed by prosecutor when lost without bad faith; only bad faith destruction violates due process).

81. See note 53 supra.

82. See, e.g., Geders v. United States, 425 U.S. 80,90 n.3 (1976) (ethical distinction between discussing testimony with witness and improperly seeking to influence it). Compare In re Ryder, 263 F. Supp. 360 (E.D. Va.), aff'd, 381 F.2d 713 (4th Cir. 1967) (improper to take money and shotgun used in bank robbery from client and withhold from police) with Freedman, Where the Bodies Are Buried: The Adversary System and the Obligation of Confidentiality, 10 CRIM. L. BuLl. 979 (1974) (not improper for defense attorneys to withhold facts obtained from client about location of two missing persons' bodies). Since information is a public commodity, an attorney's knowledge of the location of evidence does not impede the authorities from finding it themselves. See, e.g., State v. Sullivan, 60 Wash. 2d 214, 373 P.2d 474 (1962) (reversible error to make defense attorney testify about information he gave sheriff about location of missing body, which he had learned from client). When an attorney takes evidence of a crime from his client, however, this increases the likelihood that the authorities will be unable to find it. See, e.g., In re Ryder, 263 F. Supp. 360, 361-62 (E.D. Va.), aff'd, 381 F.2d 713 (4th Cir. 1967) (attorney's conduct showed he realized authorities might not find evidence taken from client); Clark v. State, 159 Tex. Crim. 187, 200, 261 S.W.2d 339, 347, cerl. denied, 346 U.S. 855 (1953) (attorney-client privilege does not protect attorney's advice to defendant to destroy murder weapon).

83. See note 14 supra.

84. Some courts have indicated that an attorney's illegal efforts to conceal material facts are less improper when motivated by loyalty to the interests of his client. See, e.g., In re Thomas, 36 F. 242, 246 (C.C.D. Colo. 1888) (no disbarment where attorney who sent agent to keep other party's witness away from deposition believed he was acting in client's best interest); In re Robinson, 140 A.D. 329, 338, 125 N.Y.S. 193, $199-200$ (1910) (attorney who advised client to leave jurisdiction rather than accept subpoena showed excessive zeal to protect client; this "does not excuse, but in some degree serves to palliate his offense"). 
volvement in basic trial strategies-such as deciding whether to call a certain witness or argue a particular defense-and his involvement in the destruction of documents or other evidence. The former involvement is a decision about how to present facts; the latter is an attempt to change them. If one party does not call a certain witness or ask a certain question, the other party can always do so. Once destroyed, however, documents are beyond recall. Thus, one involvement may simply lead to nondisclosure; the other is akin to lying. Hiding facts by destroying documents can only hinder the pursuit of truth. ${ }^{85}$

Therefore, under current ethical provisions that allow attorneys to assist clients in choosing which documents to discard before a legal action begins, the lawyer's special training and legal expertise can significantly affect the outcome. ${ }^{80}$ This involvement may even be encouraged by the Code of Professional Responsibility, since its failure to proscribe conduct implies that the conduct is proper in situations in which it serves the client's interests. ${ }^{8 t}$ This may be a serious problem for attorneys who feel uneasy about advising the destruction of documents, yet also feel a duty to serve clients as fully and zealously as possible within the bounds of the law..$^{88}$

\section{B. Unreviewable Discretion of the Lawyer}

One of the basic tenets of the adversary system is the principle that actions which may affect the outcome of legal disputes should be reviewable. ${ }^{89}$ Permitting attorneys to advise the destruction of possible

85. Destruction of a client's documentary evidence also might discourage more active efforts on the client's behalf. See Lind, Thibaut, \& Walker, Discovery and Presentation of Evidence in Adversary and Nonadversary Proceedings, 71 Mich. L. REv. 1129, 1140.43 (1973) (attorneys' willingness to search for additional information dependent on balance of facts; attorney who feels most facts on his side less likely to search for additional information).

86. This is true whether the adversary system is viewed as a means for finding the truth or simply as a proscribed social ritual with other meanings. See, e.g., Leff, supra note 76, at 1009 (trials are "connected" to games, with simplifying rules such as formal identity of players suggesting "connection" to other "cultural artifacts" like democracy). But see H. DrINKER, supra note 77, at 76 (criticizing idea that litigation is game between lawyers); Noonan, The Purpose of Advocacy and the Limits of Confidentiality, $64 \mathrm{MrcH}$. L. REv. 1485, 1490 (1966) (approving changes that make trials seem less like games).

87. E.g., Rubin, supra note 9 , at 587 (juxtaposition of permissible and criminal in Code leads inevitably to conclusion that all that is not criminal is acceptable); Schwartz, The Missing Rule of Professional Conduct, 52 L.A. B. J. 10, 15-16 (1976) (Code leaves decision whether to assist client in "not-unlawful-though-unconscionable behavior" to individual lawyer, thereby suggesting it is professionally proper to do so).

88. But see DR 7-101(B)(2) (lawyer may refuse to aid or participate in conduct he considers unlawful even though there is support for argument conduct is legal); EC 9-2 (when explicit ethical guidance does not exist, lawyer should act in manner that promotes public confidence in legal system and profession).

89. This principle even applies to the assertion of fundamental privileges. See, e.g., United States v. Mandujano, 425 U.S. 564,575 (1976) (witness pleading Fifth Amendment 
evidence so long as the destruction is not illegal violates that principle. Destruction is an irrevocable act. ${ }^{90}$ Once a document is destroyed, opponents will have difficulty reconstructing its contents through questioning, and will not be able to do so at all if they are unaware that the document ever existed. An attorney who knows he is the final judge of a document's relevance will have less incentive to act reasonably than in cases in which his judgment can later be reviewed by an opposing party or a court. ${ }^{91}$ An attorney who advises destruction of a document which could be misleading in order to avoid lengthy explanations in court may well be acting in good faith. Nevertheless, by advising destruction, the attorney effectively deprives the opposing party of the opportunity to challenge his judgment. ${ }^{22}$

In those cases in which an opposing party learns that destruction of potential evidence has occurred, the party may question the client in an attempt to develop the adverse inference. ${ }^{03}$ Despite the attorney's bias in favor of his client in advising destruction of documents, ${ }^{94}$ however, the attorney's judgment is paid unusual deference by other parties. ${ }^{95}$ The attorney's statement that he advised the destruction of documents, as in the Berkey case, may excite minimal reaction..$^{96}$ Moreover, the con-

before grand jury must submit to judicial determination of bona fides of claims and must satisfy judge that claim of privilege is not subterfuge); Schwimmer v. United States, 232 F.2d 855, 864 (8th Cir.), cert. denied, 352 U.S. 833 (1956) (assertion of attorney-client privilege does not prevent production of subpoenaed documents; court entitled to review documents to ensure they are in fact privileged).

90. The irrevocability of the act gave the court in Solow v. United States, 138 F. Supp. 812, 815-16 (S.D.N.Y. 1956), a way to distinguish Rosner v. United States, 10 F.2d 675 (2d Cir. 1926) (not obstruction of justice for individual to refuse to appear in response to informal letter from prosecutor). The distinction, the Solow court said, lay in the fact that when the witness failed to appear in the Rosner case, subsequent process could compel his appearance, whereas letters once destroyed were beyond recall. $138 \mathrm{~F}$. Supp. at 816 .

91. For example, when an attorney decides a particular document is not covered by an opponent's document demand, he knows that he may have to deal with other document demands that will encompass the document in question. The knowledge that his judgment in one instance will be reviewed by the other party and perhaps the court acts as an incentive to interpret each demand reasonably. See, e.g., Kiechel, supra note 8 (law firm failed to produce letter in response to document demand, and was embarrassed when contents came out at trial).

92. See, e.g., Griffin v. United States, 183 F.2d 990, 993 (D.C. Cir. 1950) (when there is substantial doubt, prosecution not to decide for court what is admissible or for defense what is useful); In re Henderson, 88 Tenn. 531, 539, 13 S.W. 413, 415, aff'd, 14 S.W. 488 (1890) (attorney disbarred for omitting portion of report submitted for construction to court, even though "lawyers might differ" over meaning).

93. See note 60 supra.

94. See p. 1678 and note 79 supra.

95. See, e.g., In re Eno's Will, 196 A.D. 131, 164, 187 N.Y.S. 756, 779-80 (1921) (attorney's decision that destroyed letters were irrelevant not permissible subject of comment by opposing side).

96. See notes 6 \& 7 supra. 
siderations that led the attorney to advise destruction will be protected by the attorney-client privilege.97

Because permitting attorneys to advise the destruction of possible evidence unless the act is illegal violates two principle assumptions of the adversary system of justice, a broader proscription in the Code of Professional Responsibility is desirable. Lawyers have an obligation to the judicial system that should limit their assistance to the client even in some cases when a client's actions are technically legal.98

\section{A Proposed Amendment to the Code of Professional Responsibility}

The current ambiguity about the lawyer's appropriate role in the decision to destroy potential evidence requires clarification. Attorneys should not be able to advise clients to destroy papers when the result violates principal assumptions about the adversary system. At the same time, there will always be some point at which individuals can legally destroy their possessions and documents, and they should be able to consult attorneys in order to avoid accidental liabilities.9 ${ }^{99}$ Thus the solution proposed here balances the rights of the client with the societal interest in having all possibly relevant facts available when legal claims come to trial. The solution takes account of several considerations: the need for an articulated statement of policy in the Code of Professional Responsibility; the need for a mechanism to enforce that policy; and the need to ensure that enforcement properly takes account of the differences between the kinds of clients and situations that an attorney may face.

\section{A. Statement of the Prohibition}

The Code of Professional Responsibility should prohibit attorneys from advising destruction of clients' documents, even if the destruction is not illegal, when these documents can affect materially the legal claims of others. It should not matter whether or not an action has begun, since the likelihood that destruction of possible evidence will

97. See, e.g., Drosten v. Mueller, 103 Mo. 624, 631, 15 S.W. 967,969 (1891) (attorney who advised destruction of alleged declaration not questioned as to contents); Robson v. Kemp, 5 Espinasse 52, 53, 170 Eng. Rep. 735 (K.B. 1803) (improper to question attorney who witnessed destruction of document).

98. See, e.g., EC 7-19 to 7-39 (duty of lawyers to adversary system).

99. See, e.g., Fried, supra note 79 , at 1073 (social nexus so complex ordinary laymen cannot exercise permissible autonomy without expert legal assistance); The Problem of Old Files, 44 LAw INST. J. 336, 340.41 (1970) (possible adverse consequences to clients from destruction of their papers). 
affect the rights of others does not depend on whether litigation has started. ${ }^{100}$ At the same time, given the difficulty of knowing when a document or other item of evidence will be relevant, ${ }^{101}$ the Code also should establish a rebuttable presumption that all documents are relevant after an action has begun. ${ }^{102}$ The disciplinary rule might read as follows: ${ }^{103}$

In his representation of a client, the lawyer shall not advise or assist in the destruction of documents, records or other real evidence when he knows or reasonably should know that they are relevant to any foreseeable, planned or pending action.

Such a formulation offers attorneys guidance even though enforcement may be difficult. ${ }^{104}$

This amendment does not solve the problem of attorney mistakes or errors of judgment. Moreover, it does not address the problem of interaction between a sophisticated attorney and a sophisticated client. The prohibition can be bypassed simply by advising a client that he has a legal right to destroy a document, without explicitly advising destruction. ${ }^{105}$ Some enforcement mechanism is needed to ensure

100. If ansthing, higher standards should apply to attorneys who serve as advisers rather than as adrocates, for in a courtroom there is always a lawyer on the other side. See G. HAzırd, supra note 16, at 40.41 (chance misconduct in litigation will be undetected almost certainly more remote than in other circumstances). Note that the same loyalty to clients required of lawyers who act as advocates is required of lawyers who act as adviscrs. Brown \& Brown, What Counsels the Counselor? The Code of Professional Responsibility's Ethical Considerations-A Preventative Law Analysis, 10 VAL. L. Rev. 453, 468 (1976) (adviser's primary task is determining what client wants and how he can best serve client).

101. Bul see In re Horowitz, 482 F.2d 72 (2d Cir. 1973) (to quash subpoena, petitioner must establish documents can have no conceivable relevance to any legicimate object of grand jury investigation); In re Grand Jury Subpoena, 391 F. Supp. 991, 997 (D.R.I. 1975) (relerance means "some possible relationship, however indirect"). A simple test for determining relevance might be to ask whether these are the kind of documents an opposing counsel would want to see.

102. Such a presumption, stated in an Ethical Consideration, is appropriate because proof of a document's relevance will be difficult after it has been destroyed.

103. The provision would best fit DR 7-102(A) (conduct that is prohibited during representation).

104. As is always the case, however, the problem cannot be completely solved by such a rule; cf. pp. 1673-74 sufra (shortcomings of statutes). Even so, it may be hoped that the rule would be voluntarily observed. See G. HAzARD, supra note 16, at 5 (legal ethics and formulations are properly matter of positive law with same character as any other law); Schwartz, supra note 87, at 17-18 (ethical rules have purposes other than punitive ones; they also establish peer expectations).

105. An attorney could tell a client, for example: "While I am forbidden by legal cthics to advise you to destroy this document, you should know that it could prove cmbarrassing in subsequent litigation and that you have no current legal obligation to keep it around." See, e.g., J. GouldeN, supra note 69, at 288 (anecdotal account of client who did not understand attorney's veiled suggestion to destroy incriminating papers during FTC investigation). 
compliance with the rule. Since the act of destruction forecloses review of the documents themselves, the enforcement mechanism proposed here is the attorney's disclosure in appropriate cases of the documents' contents.

\section{B. Required Disclosure by the Attorney}

Much recent criticism has been directed at the attorney's obligation to preserve the secrets and confidences of his client when this secrecy inflicts harm on third parties. ${ }^{106}$ The situations where an attorney advises his client to destroy potentially relevant evidence or concurs in his client's decision to do so are examples of this problem, since the attorney's advice may adversely affect the legal rights of others. ${ }^{107}$ Only when the documents destroyed are truly irrelevant does the attorney's conduct not interfere with the system of justice.

The "crime or tort" exception to the attorney-client privilege holds that an attorney must testify about wrongs committed by his client after the inception of the attorney-client relationship, ${ }^{108}$ whether or not the attorney is involved in the wrongful behavior. ${ }^{109}$ Destruction of documents to prevent their use at trial is viewed as a wrong inflicted on the court, ${ }^{110}$ even when it is not illegal. Therefore the attorney-client privilege should not extend to situations where the attorney advises or assists in the destruction of possible evidence.

When an opposing party makes a colorable claim that possibly relevant documents have been destroyed, ${ }^{111}$ a court should proceed on

106. See, e.g., Frankel, supra note 79, at 1057-58 (proposing amendment to Code of Professional Responsibility requiring attorneys to elicit whole truth in questioning witnesses, report untrue statements by witnesses, and state all material facts); Noonan, supra note 86 , at $1488-89$ (duty to keep communications confidential should be restricted when it leads to conduct that destroys truth or presents perjury).

107. See pp. 1678-81 supra.

108. See, e.g., Clark v. United States, 289 U.S. 1, 15 (1933) (client who consults attorney for advice that will help in commission of fraud will have no help from the law); SEC $v$. Harrison, 80 F. Supp. 226, 230 (D.D.C. 1948), vacated as moot, 340 U.S. 908 (1951) (consultations with attorney for perpetration of crime or fraudulent wrongdoing are not protected by attorney-client privilege).

109. Clark v. United States, 289 U.S. 1, 15 (1933) (loss of attorney-client privilege does not depend on showing that client and attorney equally involved in fraudulent conspiracy; attorney may be innocent but privilege will not protect client's guilty acts).

110. See p. 1675 supra. The adverse inference itself is based on the assumption that destruction is a legal wrong. See, e.g., Pomeroy v. Benton, 77 Mo. 64, 86 (1882) (by indulging a presumption which supplies that lost proof, law defeats the wrongdoer); accord, Maguire \& Vincent, Admissions Implied from Spoliation or Related Conduct, 45 YALE L.J. 226, 258 (1935) (courts may apply adverse inference rule with "punitive enthusiasm").

111. A "colorable claim" or "prima facie case" that the client harbored a wrongful purpose in seeking the consultation is necessary to overcome the attorney-client privilege on the grounds of the "crime or tort" exception. United States v. Bob, 106 F.2d 37, 40 
the basis of a pretrial motion to question the attorney in camera about his role or awareness of such conduct. ${ }^{112}$ When the court finds that relevant documents were destroyed, any information ${ }^{113}$ about their contents received from the attorney should be made available to opposing counsel, ${ }^{114}$ even when the documents were destroyed as part of a routine document retention program. The destruction would be viewed as a tort inflicted on a third party to impair its legal position, and thus outside the scope of the attorney-client privilege. The documents would lose their confidentiality as a result.

On the other hand, if the court found after general preliminary questioning ${ }^{115}$ that the documents were not relevant to the action, it should cease questioning the attorney immediately and suppress the results. ${ }^{110}$ The attorney's answers in the initial stages of such questioning would be viewed as "non-testimonial," 117 much like an attorney's answers under current law to questions about his client's identity, 118

(2d Cir.), cert. denied, 308 U.S. 589 (1939) (mere assertion of intended crime or fraud is not enough to release attorney; prima facie case must first be established); SEC v. Harrison, 80 F. Supp. 226, 232 (D.D.C. 1948), vacated as moot, 340 U.S. 908 (1951) (requisite prima facie showing of fraud not made).

112. Attorneys could also be required to submit affidavits in lieu of direct questioning.

113. Even if the attorney were unaware of the specific contents of the destroyed documents, he could still testify to the fact of their destruction. The attorney would be called to testify about the contents of the destroyed documents even in cases where he urged the client not to destroy the documents. See note 109 supra (crime or tort exception to attorney-client privilege does not depend on showing of attorney's involvement in fraud).

114. The information probably should not be attributable in court to the attorney, however. See State ex rel. Sowers v. Olwell, 64 Wash. 2d 828, 834, 394 P.2d 681, 685 (1964) (prosecution must avoid disclosing to jury source of evidence turned over by defendant's attorney).

115. General questioning would include such questions as whether the attorney participated in the destruction of any documents, whether he had been asked about the destruction of any documents by his client, whether the documents were business records or personal papers, and whether they had had any relation to the pending case.

116. See, e.g., United States v. Schmidt, 343 F. Supp. 444 (M.D. Pa. 1972), order supplemented mem., 360 F. Supp. 339 (M.D. Pa. 1973) (before examining documents on the record court ordered in camera review of affidavits potentially falling under attorneyclient privilege); A.B. Dick Co. v. Marr, 95 F. Supp. 83, 102 (S.D.N.Y. 1950), app. dismissed as moot, 197 F.2d 498 (2d Cir.), cert. denied, 344 U.S. 878 (1952) (had there been sufficient evidence of illegal conspiracy to suppress evidence of prior use in patent case, court would have required attorneys to produce documents they claimed were protected by attorney-client privilege).

117. See, e.g., Fisher v. United States, 425 U.S. 391, 409.10 (1976) (enforcement of subpoena against attorney to obtain client's document involves substantial compulsion, but was not compelled testimonial communication since preparation of document was wholly voluntary); In re January 1976 Grand Jury, 534 F.2d 719, 723 (7th Cir. 1976) (no testimonial privilege because if there was testimonial disclosure, it was that of the attorney, not that of his clients).

118. See, e.g., Fuston v. United States, 22 F.2d 66, 67 (9th Cir. 1927) (attorney must identify client as man who used false name to sign homestead petition). 
his fee, ${ }^{119}$ or his possession of subpoenaed documents. ${ }^{120}$ Thus, such preliminary answers would not violate the attorney's ethical duty to preserve the secrets and confidences of his client even in situations in which the attorney-client privilege remained unbroken. ${ }^{121}$ Finally, the attorney's testimony would not be required when the documents themselves could not have been discovered because of the client's Fifth Amendment rights. ${ }^{122}$

Two difficulties with this enforcement procedure should be recognized. First, it may impose burdens on the courts. It may be hoped, however, that the mechanism would be used rarely, ${ }^{123}$ and that it

119. See, e.g., Pollock v. United States, 202 F.2d 281, 286 (5th Cir.), cert. denied, 345 U.S. 993 (1953) (attorney must testify about receipt of cash from client used to purchase property); In re Wasserman, 198 F. Supp. 564, 566 (D.D.C. 1961) (amount of fee paid to lawyer and dates of payment not privileged communications).

120. See, e.g., Colton v. United States, 306 F.2d 633, 636 (2d Cir. 1962) (attorney-client privilege does not bar attorney from having to testify about general nature of documents in his possession and general nature of legal services performed for client); Gretsky v. Miller, 160 F. Supp. 914, 915 (D. Mass. 1958) (mere possession of documents by attorney is not privileged fact; attorney must say whether he possesses corporation's minutes and stock certificate book).

121. See note 16 supra (duty to preserve secrets and confidences of client).

122. The Supreme Court has often recognized that the Fifth Amendment does not protect documents of a sufficiently economic or public nature. See, e.g., Bellis v. United States, 417 U.S. 85 (1974) (Fifth Amendment privilege does not apply to partnership records of individual partners); Wilson v. United States, 221 U.S. 361, 374-75 (1911) (Fifth Amendment privilege does not apply to individual holders of corporate records). In some situations, papers required to be kept by law also lose their Fifth Amendment protection. E.g., Shapiro v. United States, 335 U.S. 1 (1948) (Fifth Amendment does not prevent prosecution for pricing violations on basis of records individual required by law to keep).

This provision thus recognizes the basic differences between disclosure of a client's personal papers and disclosure of business or public records. See, e.g., Fisher v. United States, 425 U.S. 391, 426-27 (1976) (Brennan, J., concurring in judgment) (suggesting hierarchy for protection of documents in applications for search warrants, ranging from documents created by government, to corporate business records, to personal notes and diaries). The rule that the Fourth and Fifth Amendments exclude an individual's private papers from use against him at trial and secure them from judicial process is viewed as an expression of respect for the privacy and dignity of the individual. Warren \& Brandeis, The Right to Privacy, 4 HARv. L. REv. 193, 205 (1890).

There should be no question about the attorney's duty to raise his client's Fifth Amendment rights when he is called on to disclose the contents of incriminating documents. In re Terkeltoub, 256 F. Supp. 683, 686 (S.D.N.Y. 1966) (court cannot compel attorney to answer questions about client's attempt to influence witness where attorney raised client's Fifth Amendment privilege). But see State ex rel. Sowers v. Olwell, 64 Wash. 2d 828, 836, 394 P.2d 681, 686 (1964) (attorney cannot use client's Fifth Amendment privilege to withhold physical evidence).

123. It seems likely that the enforcement mechanism would serve primarily as a deterrent, since opponents would have to suspect the prior existence of the destroyed documents before they could make the showing necessary to break the attorney-client privilege. In that case, they might just as easily cross-examine the client on the stand as invoke proceedings against the client's attorney. But see Note, client Fraud and the Lawyer-An Ethical Analysis, 62 MinN. L. Rev. 89, 117 (1977) (to extent that clients are aware of lawyer's duty to reveal fraud, they may be less likely to engage in such conduct in the first place). In cases where a showing is attempted, the burden may not be as great 
would operate primarily as an incentive for attorneys to follow the proposed amendment to the Code of Professional Responsibility. Only the possibility of later scrutiny can solve the problem of the otherwise unreviewable discretion of attorneys to decide when a document is relevant, ${ }^{124}$ and thus an enforcement mechanism is necessary to implement the new Code prohibition.

A second difficulty is that the possibility of attorney disclosure, even in rare situations, may impede communication between client and attorney over the contents of possibly damaging documents. The client may have an incentive to hide facts from his lawyer; the lawyer may tell the client not to show him documents related to a particular matter. ${ }^{125}$ This will be true, however, only in cases where the future destruction of the documents is contemplated. ${ }^{126}$ Moreover, 'the attorney has an ethical duty to seek information from his client, ${ }^{127}$ and the client may not know that documents are legally damaging or embarrassing until after he has shown them to his attorney. In any event, in situations where damaging documents exist, there should be incentives for the lawyer either to explain the document in court or else

as it might first scem. See, e.g., McDowell Associates, Inc. v. Penn. R.R., 20 F.R.D. 219, 221 (S.D.N.Y. 1957) (document demand upheld since "the inference is clear that defendant did maintain such records," and defendant did not deny their existence).

The deterrent effect of the enforcement mechanism is thus two-fold: the client will be discouraged from committing perjury regarding the reasons for destruction or the contents of the destroyed documents, and the attorney will try to persuade the client not to destroy relevant documents so as to avoid the risk that the attorney will later be questioned. While the enforcement mechanism can still be evaded where the attorney gives general advice about destruction but does not learn the contents of particular documents and thus cannot reveal them, the attorney would still have to testify about his role in the destruction, see note 113 supra, and the adverse inference rule would remain as an additional deterrent, see note 126 infra. Moreover, such conduct would constitute a blatant violation of the attorney's ethical duties.

124. See pp. 1681-82 supra.

125. See Freedman, supra note 27 , at $1472-74$ (if defense attorney had duty to reveal client's perjury, client would be less open with attorney). See generally $8 \mathrm{H}$. WIGMoRE, EvidencE $\$ 2290$ (3d ed. 1940) (purpose of attorney-client privilege is to encourage clients to place full confidence in attorneys without fear of disclosure of secrets).

126. Since the client will have to testify about the contents of destroyed documents if the opposing side learns of the destruction, any hesitation to show the documents to the client's attorney may also depend on the client's intention to lie about the contents if questioned. Note that the adverse inference still permits jury consideration of the destruction of evidence even in situations where the attorney would not have a duty to testify about the destruction. See, e.g., Rogers v. Exxon Research \& Eng'r Co., 550 F.2d 834, 843 (3d Cir. 1977), cert. denied, 434 U.S. 1022 (1978) (evidence of plaintiff's destruction of private diaries after start of litigation and after showing them to his attorney should have been admitted; reasons for destruction were matter for argument to jury); United States v. Marchesani, 457 F.2d 1291, 1298 (6th Cir. 1972) (proper to instruct jury on spoliation inference in criminal trial).

127. See DR 6-101(A)(2) (lawyer shall not handle legal matters without adequate preparation); ABA Code of Professional Responsibility, Canon 6 (lawyer should represent client competently). 
settle the case, rather than encourage destruction of possibly relevant evidence.

In the end, this proposal represents a judgment that the need to ensure that attorneys do not participate in conduct that is an acknowledged legal wrong outweighs the risks of impeded communication between an attorney and client and increased burdens on the courts. The same analysis applies to any "crime or tort" exceptions to the attorney-client privilege. While attorneys cannot enforce standards of conduct for their clients that are not required by law, ${ }^{128}$ a client who takes a document to his attorney must expect that it will either be preserved for use in the judicial system or else that his attorney may be required to show that the evidence was not relevant to the later legal action. ${ }^{129}$ Such an enforcement mechanism is required to solve problems of review and is justified by the fact that destroying evidence to prevent its use in the legal system goes beyond the assistance an attorney can properly render to his client.

\section{Conclusion}

The Code of Professional Responsibility should be amended to prohibit attorneys from advising clients to destroy documents or other evidence that might be relevant to pending, planned or foreseeable legal actions, even when the destruction is not illegal. ${ }^{130}$ Attorneys should not be free to change the nature of the facts available to future adversaries-which is the effect of destroying evidence-for this threatens basic assumptions about the adversary system. The attorney-client privilege should not protect the contents of documents when the attorney advised or assisted in their destruction.

128. But see G. HAZARD, supra note 16, at 146 (although lawyer "cannot be held responsible for everything his client does, it is equally clear that he must assume responsibility at some point").

129. The tort which the attorney-client privilege should not cover is that of destroying evidence with intent to keep it from being used in a later legal action, and it is the lawyer's involvement and advice which demonstrates that intention where the documents prove to be relevant.

130. These suggestions should help meet Judge Frankel's concern for "restricting latitude for falsification, for concealment of the truth," Address, Nov. 1, 1978, Yale Law School, without requiring as radical a change in the nature of the adversary system as he has proposed. See Frankel, supra note 79. 